\title{
Introduction of the anti-apoptotic baculovirus $p 35$ gene in passion fruit induces herbicide tolerance, reduced bacterial lesions, but does not inhibits passion fruit woodiness disease progress induced by cowpea aphid-borne mosaic virus (CABMV)
}

\author{
Daniele Scandiucci de Freitas • Marly C. Felipe Coelho • \\ Manoel T. Souza Jr. • Abi Marques - Bergmann Morais Ribeiro
}

Received: 7 July 2006/Revised: 25 August 2006/ Accepted: 25 August 2006/

Published online: 3 October 2006

(C) Springer Science+Business Media B.V. 2006

\begin{abstract}
The introduction of anti-apoptotic genes into plants leads to resistance to environmental stress and broad-spectrum disease resistance. The anti-apoptotic gene (p35) from a baculovirus was introduced into the genome of passion fruit plants by biobalistics. Eleven regenerated plants showed the presence of the $p 35$ gene by PCR and/or dot blot hybridization. Transcriptional analysis of regenerated plants showed the presence of specific p35 transcripts in 9 of them. Regenerated plants containing the $p 35$ gene were inoculated with the cowpea aphid-borne mosaic virus (CABMV), the bacterium Xanthomonas axonopodis pv passiflorae, and the herbicide, glufosinate, (Syngenta). None of the plants showed resistance to CABMV. Regenerated plants $(p 35+)$ showed less than half of local lesions showed by non-transgenic plants when inoculated with $X$. axonopodis and some p35+ plants showed increased tolerance to the glufosi-
\end{abstract}

D. S. de Freitas · B. M. Ribeiro ( $₫)$

Departamento de Biologia Celular, Univesidade de Brasília, Brasília, DF CEP 70910-900, Brasil e-mail: bergmann@unb.br

M. C. F. Coelho · M. T. Souza Jr.A. Marques Embrapa-Recursos Genéticos e Biotechnologia Parque Estação Biológica, PqEB, Av. W5 Norte (final), Caixa Postal 02372, Brasília, DF 70770-900, Brasil nate herbicide when compared to non-transgenic plants.

Keywords Apoptosis $\cdot$ Baculovirus $\cdot$ Herbicide tolerance $\cdot$ Passiflora $\cdot$ p35 gene

\section{Introduction}

Brazil is the biggest producer of passion fruit (Passiflora spp). The total planted area in 2002, according to the Brazilian Institute for Statistics and Geography (IBGE), was 34,778 ha, with a yield of 478,652 fruits. The yield of a crop is dependent on several factors, including climate, soil and phytopathogen control. Phytopathogens cause yield losses in practically all cultivated crops and new, more efficient and cheaper methods for disease control have been developed. One such method is the construction of transgenic crops resistant to fungi, bacteria and viruses.

Programmed cell death (PCD) provides a means to eliminate redundant, damaged or microbe-infected cells; PCD is a physiological and genetically controlled process involved in the selective elimination of unwanted cells during development of multicellular organisms and in their responses to biotic and abiotic stresses (Del Pozo and Lam 2003, Khurana et al. 2005).

In animals, PCD is characterized by a number of hallmark features including cell shrinkage, 
plasma membrane blebbing, nuclear condensation, inter-nucleosomal cleavage and externalization of plasma membrane phosphatidylserine, which leads to fragmentation of DNA and formation of apoptotic bodies that migrate to the periphery of the cell for eventual phagocytosis by neighbouring macrophages (Chen and Dickman 2004). In plants, several tissues or whole organs undergo cell death as part of their normal development. Although the mechanisms of plant PCD are far less clear, several morphological and biochemical similarities between PCD in animals and plants have been described in different experimental systems, including condensation and shrinkage of the nucleus and cytoplasm, DNA laddering, and cytochrome c release from mitochondria (Chichkova et al. 2004).

Baculoviruses belong to a group of viruses restricted to arthropod hosts and have been used around the world as biological control agents, expression vectors for foreign genes in insect cells and potential non-human viral vectors for gene therapy (Ghosh et al. 2002). Baculoviruses have two types of anti-apoptotic genes: $p 35$ and inhibitor of apoptosis (iap) genes. They are able to inhibit apoptosis not only in infected insect cells, but also in different organisms. Other organisms also have anti-apoptotic genes, for example the ced-9 gene in Caenorhabditis elegans and the $\mathrm{Bcl}$ 2 gene in humans. These anti-apoptotic genes code for proteins that inhibit directly or indirectly the activity of members of a family of cysteine proteases called caspases (Clem 2001).

The expression of anti-apoptotic genes such as iap, p35, bcl-2 and ced-9 in tobacco or tomato plants suppressed the extensive cell death caused by necrotrophic fungal pathogens and also enhanced resistance to some abiotic stresses such as wounding, salt, cold, UV, and herbicide (Paraquat) treatment (Xu et al. 2004; Chen and Dickman 2004; Lincoln et al. 2002; Dickman et al. 2001; Li and Dickman 2004).

In this work, we have introduced the p35 gene of a baculovirus into the genome of passion fruit plants and demonstrated that the transformed plants were more tolerant to an herbicide and a bacterial pathogen, Xanthomonas axonopodis, pv passiflorae. However, no resistance or tolerance was observed for the infection with the virus cowpea aphid-borne mosaic virus (CABMV).

\section{Materials and methods}

Plasmid construction and plant transformation

The p35 gene of the baculovirus, Autographa californica multiple nucleopolyhedrovirus (AcMNPV), was excised from the plasmid pPRM35KORF (Hershberger et al. 1994) by BamHI digestion and cloned into the BamHI site of the pEPT8 plasmid (Souza Jr and Gonsalves 1999), under the $35 \mathrm{~S}$ cauliflower mosaic virus promoter and into the pBSAN236 plasmid (Callis et al. 1995), under the UBQ3 promoter from Arabidopsis thaliana (Fig. 1) using standard molecular cloning techniques (Sambrook et al. 1989). The positive clones containing the p35 gene (pEPT8p35 and pBSAN236p35, respectively) were confirmed by sequencing (ABI Prism 3700, Applied Biosystems).

Passion fruit (Passiflora edulis f. flavicarpa Deg.) hipocotyles were cultivated in vitro, and pieces of around $4 \mathrm{~mm}$ were removed and transferred to regeneration medium [4.3 g Murashige \& Skoog Salt Mixture (Invitrogen), $10 \mathrm{ml} \mathrm{B5}$ vitamin, $0.1 \mathrm{~g}$ myo-inositol, $2.8 \mathrm{~g}$ Phytagel (Sigma-Aldrich Biotechnology), $30 \mathrm{~g}$ sucrose, $1 \mathrm{mg}$ BAP (6-benzilaminopurine), in one liter of water, $\mathrm{pH}$ 5.7]. They were maintained at $27^{\circ} \mathrm{C} \pm 2{ }^{\circ} \mathrm{C}$ with $16 / 8 \mathrm{~h}$ light/dark periods in an environmental chamber. The explants were then bombarded with pEPT8p35 or pBSAN236p35, as described by Aragão et al. (1996) and, after $24 \mathrm{~h}$, the explants were transferred to new regeneration medium. Every 15 days the medium was changed until the plants were regenerated (around 60 days). The regenerated plants were transferred to elongation medium (Murashige \& Skoog Salt Mixture and $1 \mathrm{mg}$ zeatin $\mathrm{l}^{-1}$ ) and when the plants were $5 \mathrm{~cm}$ tall, they were transferred and maintained in recipients containing $75 \%(w / w)$ soil, $25 \%(\mathrm{w} / \mathrm{w})$ sand and acclimated in a greenhouse.

DNA analysis of regenerated plants

DNA from regenerated plants were extracted following the protocol described in Sambrook 
Fig. 1 Construction of the pEPT8p35 and pBSAN236p35 plasmids used for the transformation of passion fruit plants. Schematic representation of the plasmids pEPT8 (A), pPRM 35K-ORF (B), pEPT8p35 (C), pBSAN236 (D) and pBSAN236p35 (E). The plasmids pEPT8 and pBSAN236 were digested with BamHI and ligated to the $p 35$ gene that was removed from the plasmid pPRM 35K-ORF by digestion with the same enzyme. The figure also shows the position of restriction sites, the $35 \mathrm{~S}$ and UBQ3 promoters, the ampicillin resistance gene (ampR) and transcription termination site (NOSter). The plasmids are not drawn to scale

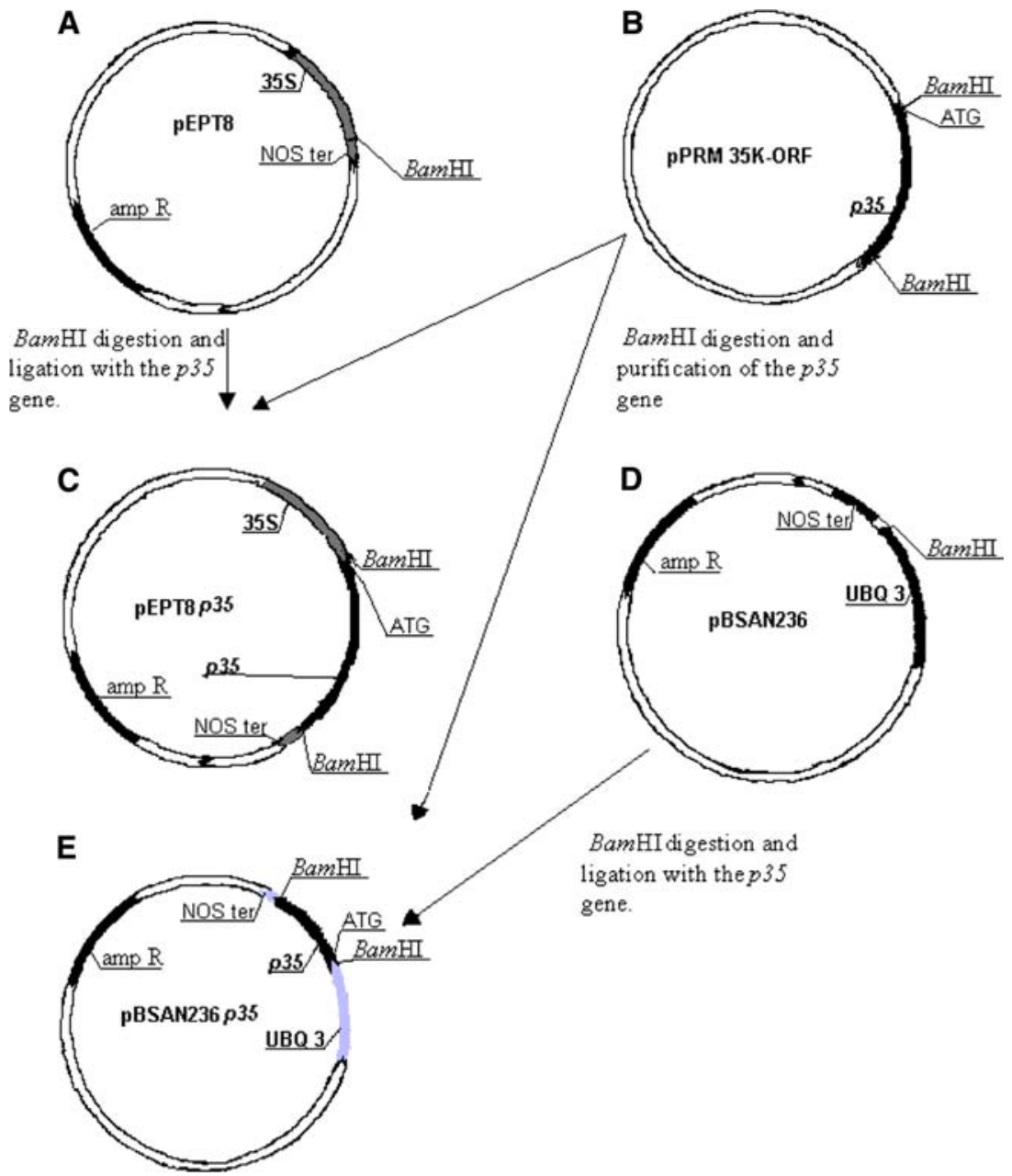

et al. (1989) and a PCR reaction was set up using $50 \mathrm{ng}$ total DNA and p35 specific oligonucleotides Acp351-22F (5'-ATGTGTGTAATTTTTCCGGTAG-3') and 443Acp35R (5'-TAGT CGTTGCGTTCGTCGACC-3') or p35F433 (5'-GCAACGACTACTACGTGGC-3') and p35R533 (5'-GCAACGACTACTACGTGGC$\left.3^{\prime}\right)$. As a positive control, $25 \mathrm{ng}$ of the plasmid pPRM-35KORF and, as a negative control DNA, $50 \mathrm{ng}$ from non-transformed plants. The following PCR programmes were used for the two sets of oligonucleotides: $96^{\circ} \mathrm{C} / 10 \mathrm{~min}$ and 30 cycles of $96^{\circ} \mathrm{C} / 1 \mathrm{~min}, 46^{\circ} \mathrm{C} / 1 \mathrm{~min}$ and $72^{\circ} \mathrm{C} / 1 \mathrm{~min}$ (for the first set) or $96^{\circ} \mathrm{C} / 10 \mathrm{~min}$ and 30 cycles of $96^{\circ} \mathrm{C} /$ $1 \mathrm{~min}, 56^{\circ} \mathrm{C} / 1 \mathrm{~min}$ and $72^{\circ} \mathrm{Cl} 1 \mathrm{~min}$ (for the second) in a Gene Amp PCR System 2400 (Applied Biosystems). The amplified fragments were analyzed by $1 \%$ agarose gel electrophoresis as described in Sambrook et al. (1989). After electrophoresis, the amplified PCR fragments from the PCR reaction using the pair of oligonucleotides Acp351-22F and 443Acp35R, were transferred to a nitrocellulose membrane (Sambrook et al. 1989), which was incubated with a p35-specific radioactive probe using standard protocols (Sambrook et al. 1989). The radioactive probe was constructed by digesting the plasmid pPRM-35KORF with BamHI, separating the digested fragments in a $1 \%$ agarose gel by electrophoresis, and purifying the fragment containing the $p 35$ gene using the GFX band prep kit (GE Healthcare) following the manufacturer's instructions. The purified fragment was used for the production of the probe using the Random 
Primers Kit (Promega), following the supplier's instructions. The membrane was incubated for $16 \mathrm{~h}$ at $65^{\circ} \mathrm{C}$ with the probe and washed under stringent conditions. The membrane was then exposed to an X-ray film (Kodak) for a week at $80^{\circ} \mathrm{C}$ and the film was developed as described in Sambrook et al. (1989).

Transcription analysis

Total RNA from transgenic (p35+) and nontransgenic plants (0.2 $\mathrm{g}$ of fresh leafs) were extracted as described in Sambrook et al. (1989) and used for the production of cDNA using the poli-A specific oligonucleotide T1 (5'-CCT GCAGGATCCTTAGGTTTTTTTTTTTTTTTT TT-3') and the Mu-MLV reverse transcriptase (Invitrogen), following the manufacturer's instructions. A PCR reaction was set up using Taq DNA Polymerase (Invitrogen), the constructed cDNA and the oligonucleotides T2 (5'CCTGCAGGATCCTTAGGTT-3'), which is identical to the first 19 bases of the oligonucleotide $\mathrm{T} 1$ and the $p 35$ gene specific oligonucleotide, 433Facp35 (5'-GCAACGACTACTACGTGGC$\left.3^{\prime}\right)$, which anneals at positions +433 to +451 relative to the start codon of the p35 gene (GeneBank accession number: M16821). The PCR programme used was the same used for the amplification of the p35 gene from the transgenic plant genome (see above). In order to confirm the specificity of the transcripts, the amplified PCR fragments were subjected to a new PCR reaction using the p35F433 and p35R533 pair of oligonucleotides following the protocol described above.

Virus inoculation

Leaves (5g) were removed from passion fruit plants infected with passion fruit woodiness disease (PWD), caused by cowpea aphid-borne mosaic virus (CABMV) and grinded in $10 \mathrm{ml}$ phosphate buffer pH $7.0(0.02 \mathrm{~m})$ and the extracts were mechanically inoculated in transgenic and non-transgenic plants (previously treated with an abrasive, carborundum). The inoculated plants were then maintained in a green house and observed daily.
Herbicide treatment

Leaves from one year old passion fruit plants (transgenic and non-transgenic) were collected and washed in $70 \%(\mathrm{v} / \mathrm{v})$ ethanol for $1 \mathrm{~min}$, $0.25 \%$ sodium hypochlorite for $15 \mathrm{~min}$ and rinsed three times in sterile $\mathrm{H}_{2} \mathrm{O}$. The leaves were then cut into $1 \mathrm{~cm}^{2}$ pieces and transferred to Petri dishes containing regeneration medium and $0.06 \%$ glufosinate (Syngenta). They were evaluated after 3 and 6 days post-incubation. The experiment was repeated three times.

Bacteria inoculation

Xanthomonas axonopodis pv passiflorae, from the Phytopatology Laboratory at University of Brasília, Brazil, was first inoculated in a non-transgenic passion fruit plant for amplification and evaluation of pathogenicity. As soon as the first symptoms appeared (necrotic lesions), bacteria were recovered in culture media and used to inoculate p35+ plants. All plants were maintained in a humid chamber from 24 to $48 \mathrm{~h}$ prior to bacterial inoculation. Two different samples at approximately $10^{6}$ and $10^{8} \mathrm{cfu}$ of $X$. axonopodis $/ \mathrm{ml}$ were inoculated by aspersion onto two leaves each. The plants were incubated in a greenhouse and local lesions were counted at day 10 .

\section{Results}

Construction and selection of transgenic passion fruit plants

The p35 gene of the baculovirus AcMNPV was introduced into the plasmids pEPT8 and pBSAN236 under the transcriptional control of the $35 \mathrm{~S}$ and UBQ3 promoters, respectively (Fig. 1). Thirty passion fruit plants from explants bombarded with the plasmids pEPT8p35 and pBSAN236p35 were regenerated. DNA analysis by PCR using two sets of oligonucleotides (Acp351-22F/443Acp35R and p35F433/ p35R533) and Southern blotting of amplified fragments from one set of oligos (Acp351-22F/ $443 \mathrm{Acp} 35 \mathrm{R}$ ) showed the presence of the $p 35$ gene in 11 regenerated plants $(\mathrm{A}, \mathrm{B}, \mathrm{C}, \mathrm{D}, \mathrm{E}, \mathrm{F}, \mathrm{G}, \mathrm{H}, \mathrm{I}$, 
J, and K) (Fig. 2). Eight out of 11 regenerated plants (A, B, C, D, E, F, G, H) had the p35 gene under the control of the UBQ3 promoter and three (I, J, K) under the $35 \mathrm{~S}$ promoter. Another PCR reaction using another set of oligonucleotides (p35F433 and p35R533) showed the presence of a single band of the expected size (100 bp) in the same 11 regenerated plants (Fig. 2C).

The transgenic plants containing the p35 gene did not show any morphological or developmental alterations when compared to non-transgenic plants.

Transcription analysis

Total RNA from eleven PCR positive plants that were positive for the presence of the p35 gene were used in a RT-PCR reaction using a poly-A specific oligonucleotide and a p35 specific oligonucleotide. An amplification product of around $500 \mathrm{bp}$ was detected in 9 of the 11 transgenic plants (A, C, D, E, F, G, I, J, K) (Fig. 2D). The specificity of the amplified fragment was confirmed by PCR using the p35F433 and p35R533 oligo pair (not shown).

\section{CABMV infection analysis}

Eleven regenerated plants (p35+) and control plants were inoculated with CABMV-infected passion fruit leaf extracts and analyzed for symptoms. None of the transformed plants showed resistance to CABMV. Fifteen days after incubation, control plants and some regenerated plants (B, E, H, I, J and K) showed mosaic symptoms (Fig. 3). Twenty days after inoculation some regenerated plants $(A, C, D, F$ and $G$ ) showed

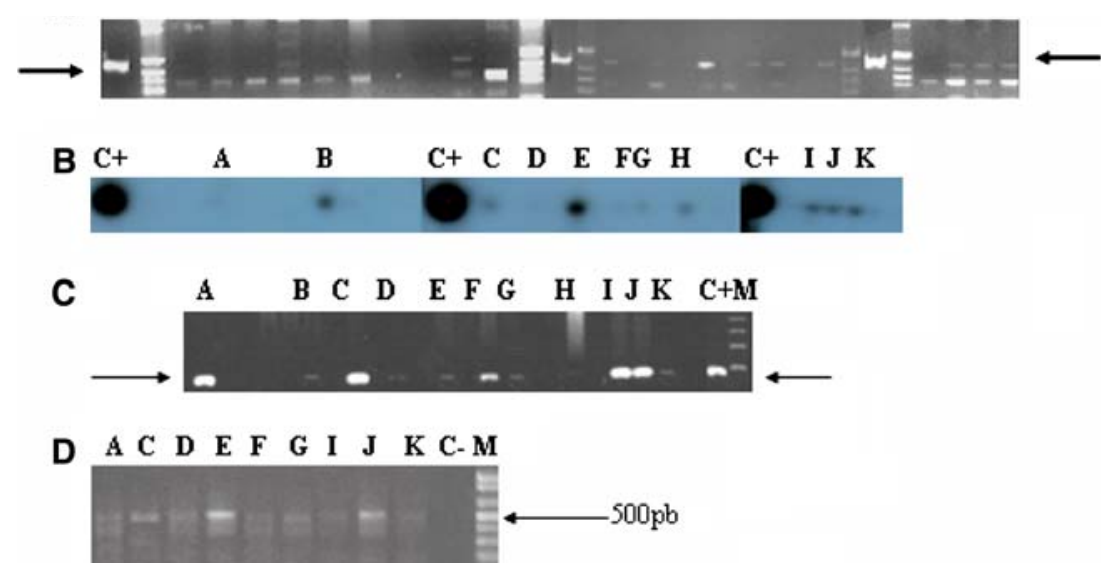

Fig. 2 Detection of the $p 35$ gene and $p 35$ transcripts in regenerated passion fruit plants. (A) Agarose gel (0.8\%) electrophoresis of PCR products from regenerated plants using oligonucleotides specific for the $p 35$ gene (Acp351$22 \mathrm{~F}$ and $443 \mathrm{Acp} 35 \mathrm{R}$ ). The expected amplified product of $457 \mathrm{bp}$ (arrow) and non-specific fragments were amplified in 11 plants (A, B, C D, E, F, G, H, I, J and K). C+ shows the amplification of the p35 gene using the same oligonucleotides and DNA from the plasmid pEPT8p35 as a positive control. $\mathrm{M}$ indicates the molecular mass marker $1 \mathrm{~Kb}$ DNA ladder (Invitrogen). (B) Autoradiograph of a Southern blot using a membrane containing the DNAs from the agarose gel shown in A. Only the plants that showed the expected PCR fragment were labelled, indicating the specificity of the amplified fragment. The probe was constructed using the $p 35$ gene radiolabelled with $\mathrm{P}^{32}$. (C) Agarose gel $(0.8 \%)$ electrophoresis of PCR products from regenerated plants using a second pair of oligonucleotides specific for the p35 gene (p35F433 and p35R533). The expected amplified product of $100 \mathrm{bp}$ (arrow) was amplified from the DNA of the same 11 plants detected with the first PCR reaction using a different pair of oligonucleotides. $\mathrm{M}$ indicates the molecular mass marker 123-bp DNA marker (Invitrogen). C + is the same as in A. (D) Agarose gel electrophoresis (0.8\%) of RT-PCR products from mRNA extracted from regenerated passion fruit plants. Eight (A, C, D, E, F, G, I, J and $\mathrm{K})$ out of eleven plants yielded an expected amplicon of around $500 \mathrm{bp}$, indicating the p35 gene was transcribed in these plants. $\mathrm{M}=$ molecular mass marker $100 \mathrm{bp}$ DNA ladder (BioLabs). The specificity of the amplified fragment was confirmed by PCR using the p35F433 and p35R533 oligo pair (not shown) 
Fig. 3 Leaf symptoms in transgenic and nontransgenic passion fruit plants induced by cowpea aphid-borne mosaic virus (CABMV). Transgenic and non-transgenic plants were inoculated with CABMV and analyzed for symptoms during 45 days. All plants (transgenic and nontransgenic) showed the presence of mosaicism (A and $\mathbf{B}$ ), leaf malformation (B) and chlorosis (C). (D) shows a healthy (not inoculated) leaf from a non-transgenic plant. Bar $=2 \mathrm{~cm}$
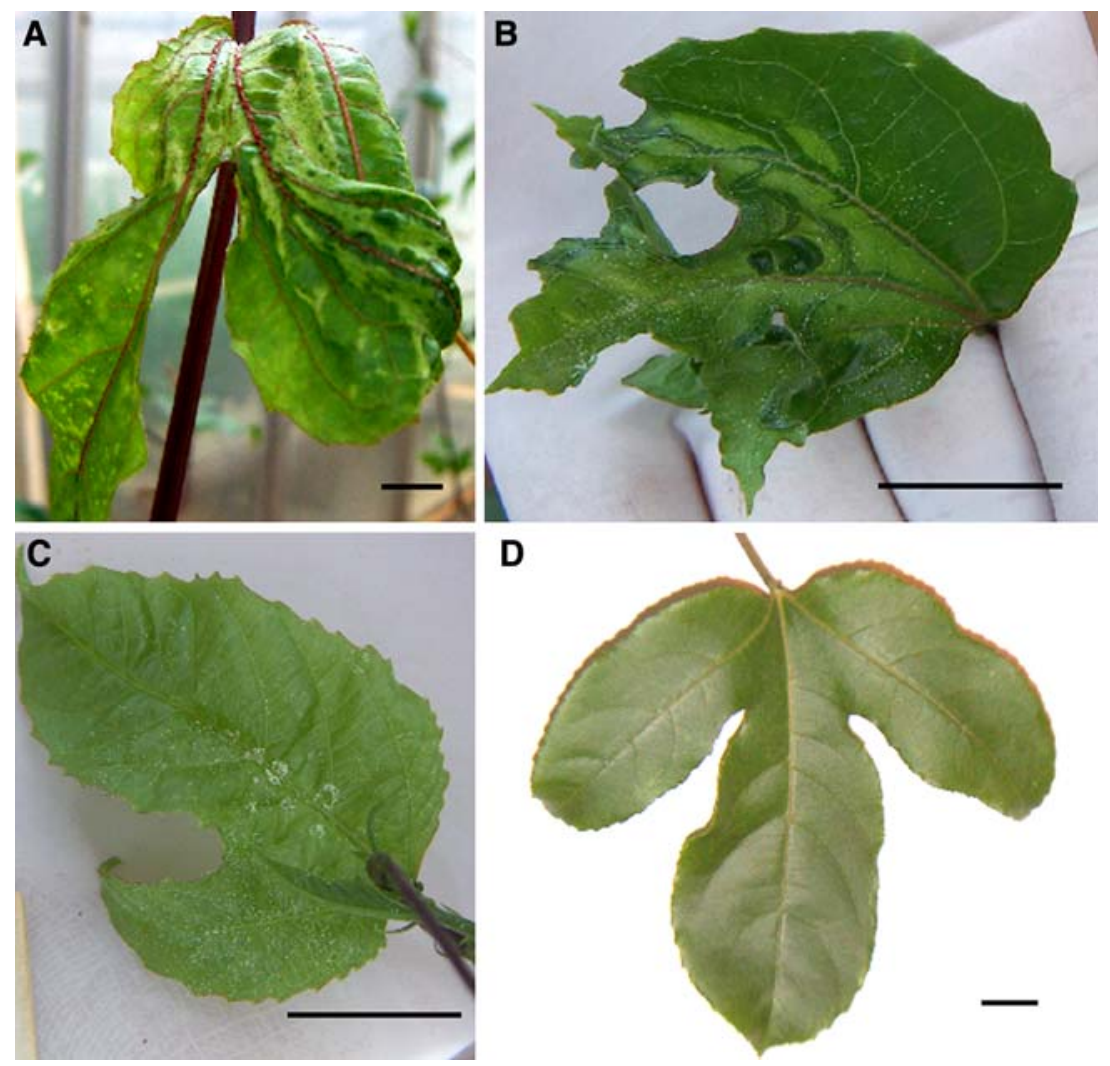

chlorotic and deformed leaves (Fig. 3). One month after inoculation, the same plants that showed chlorotic leaves and malformation had progressed to death of tendril and apical bud. At 45 days after inoculation, the new buds from these regenerated plants started showing mosaic symptoms and deformed leaves, similar to nontransgenic control plants.

\section{Herbicide treatment}

One square centimetre pieces of leaves from control and eleven regenerated plants (A, B, C, $\mathrm{D}, \mathrm{E}, \mathrm{F}, \mathrm{G}, \mathrm{H}, \mathrm{I}, \mathrm{J}$, and $\mathrm{K}$ ) were incubated on Petri dishes with or without $0.06 \%$ glufosinate. Leaf pieces from control plants incubated with the herbicide $(\mathrm{Ck}+)$ showed a substantial fading of the green colour (chlorophyll). Leaf pieces from some regenerated plants (C, F and I) treated with herbicide showed results similar to control plants that were not treated with herbicide, that is, little or no chlorophyll loss. Other leaf pieces (A, D, G, J and $\mathrm{K}$ ) showed some loss of chlorophyll and leaf pieces B, E and $\mathrm{H}$ showed the same loss as control plants treated with herbicide (Fig. 4). Transgenic plants pulverized with the herbicide $(0.06 \%$ glufosinate $)$ showed small lesions on leaves after seven days. Conversely, non-transgenic plants lost all leaves in seven days and died in up to ten days (data not shown). Furthermore, transgenic plants survived three times longer than non-transgenic ones (data not shown).

\section{Bacteria inoculation}

Leaves of seven $p 35+$ regenerated plants (A, B, $\mathrm{D}, \mathrm{F}, \mathrm{I}, \mathrm{J}$ and $\mathrm{K}$ ) and two control plants were inoculated, respectively with $10^{6}$ and $10^{8} \mathrm{cfu}$ of $X$. axonopodis $/ \mathrm{ml}$. Most of the leaves (A, D, F, $\mathrm{I}$, $\mathrm{J}$ and $\mathrm{K}$ ) displayed small local lesions (1$2 \mathrm{~mm}$ ) that were in number less than half of the amount of lesions in non-transgenic plants (Table 1). Furthermore, the lesions in p35+ 


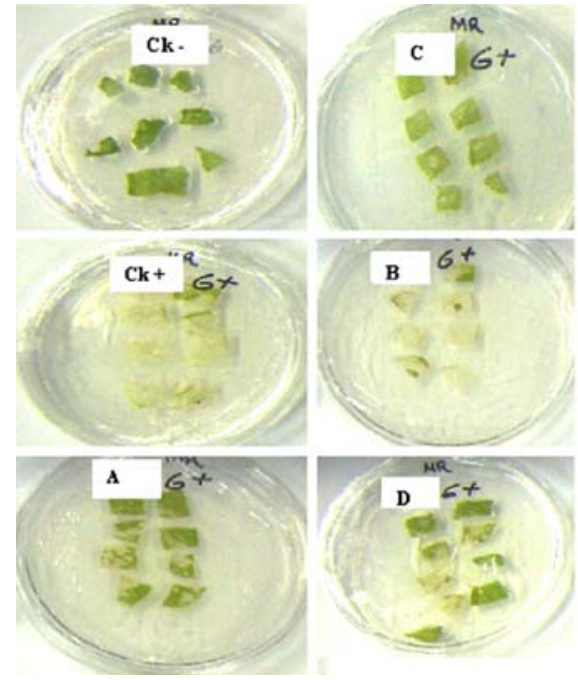

Fig. 4 Herbicide effects on leaves from transgenic and non-transgenic plants. One square centimetre leaf pieces from control and eleven regenerated plants (A, B, C, D, E, F, G, H, I, J and K) were incubated on Petri dishes with or without $0.06 \%$ glufosinate. Leaf pieces from control plants incubated with the herbicide $(\mathrm{Ck}+)$ showed a remarkable fading of their green colour (chlorophyll). Leaf pieces

Table 1 Number of $X$. axonopodis induced lesions on leaves of transgenic and non-transgenic passion fruit plants. Around $10^{6}$ and $10^{8} \mathrm{cfu}$ of $X$. axonopodis $/ \mathrm{ml}$ were inoculated by aspersion on two leaves each and the plants were incubated in greenhouses and observed daily for the appearance of local lesions. The number of lesions was counted at day 10 . The results are the average of lesion number of the two leaves

\begin{tabular}{lll}
\hline & $\begin{array}{l}\text { Number of leaf lesions caused } \\
\text { by inoculation with } X . \\
\text { axonopodis at: }\end{array}$ \\
\hline Plant & $10^{6}$ c.f.u./ml & $10^{8}$ c.f.u./ml \\
Non-trangenic plant 1 & 23 & 80 \\
Non-trangenic plant 2 & 20 & 88 \\
A & 11 & 32 \\
C & 3 & 30 \\
F & 10 & 40 \\
I & 2 & 42 \\
J & 3 & 6 \\
K & 13 & 18 \\
\hline
\end{tabular}

plants appeared later (10 days after inoculation) than in non-transgenic plants (7 days after inoculation) (Fig. 5). Lesions in two p35+ plants ( $\mathrm{B}$ and $\mathrm{H}$ ) were of comparable size to those in control plants.

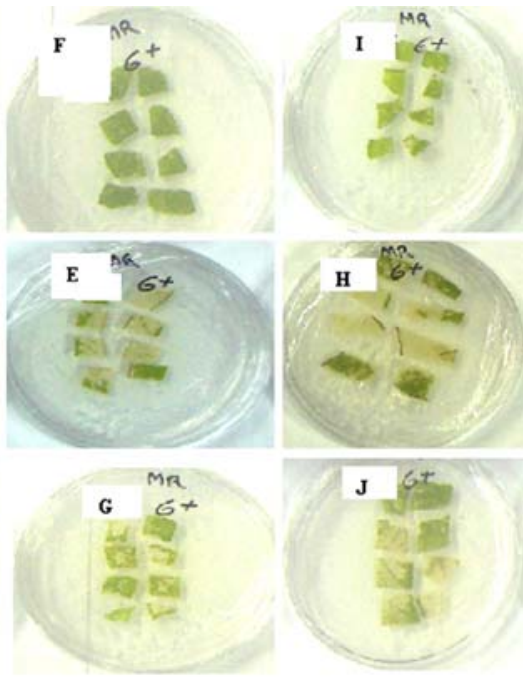

from some regenerated plants $(\mathrm{C}, \mathrm{F}$ and $\mathrm{I})$ treated with herbicide showed similar results as the control plants that were not treated with herbicide, with little or no loss of chlorophyll. Other leaf pieces $[\mathrm{A}, \mathrm{D}, \mathrm{G}, \mathrm{J}$ and $\mathrm{K}$ (not shown)] showed some loss of chlorophyll whereas pieces $\mathrm{B}, \mathrm{E}$ and $\mathrm{H}$ showed the same loss of chlorophyll as the control plants treated with herbicide

\section{Discussion}

Plants undergo programmed cell death in response to several stimuli, such as senescence, or in response to pathogens and environmental stresses. Transgenic plants expressing anti-apoptotic genes show resistance to environmental stresses and necrotrophic pathogens (Khurana et al. 2005). In this work, we have introduced the anti-apoptotic $p 35$ gene from a baculovirus into the genome of passion fruit and analyzed the response of transgenic plants to viral and bacterial infections and to herbicide treatment. None of the transgenic plants showed developmental alteration when compared to non-transgenic plants. Xu et al. (2004), constructed transgenic tomato plants containing anti-apoptotic genes $b c l-x L$ and ced-9 and demonstrated that those plants had a reduced growth. This effect was also observed in transgenic tobacco plants containing the $b c l-2, b c l-x L$ or $c e d-9$ genes (Dickman et al. 2001). However, Del Polzo and Lam (2003), like us, could not detect changes on growth of tobacco plants expressing baculovirus anti-apoptotic genes (iap or p35). 
Fig. 5 Bacterial lesions on leaves of transgenic and non-transgenic passion fruit plants. Leaves of seven $p 35+$ regenerated plants and control plants were inoculated with $10^{6}$ and $10^{8}$ cfu of Xanthomonas axonopodis $/ \mathrm{ml}$ respectively. Most $p 35+$ plants (B) showed small local lesions (1-2 mm) 10 days after inoculation, and their number was half of that observed in control plants (A), which appeared 7 days after inoculation. (C) Healthy, non-transgenic and not inoculated leaf.

Bar $=2 \mathrm{~cm}$
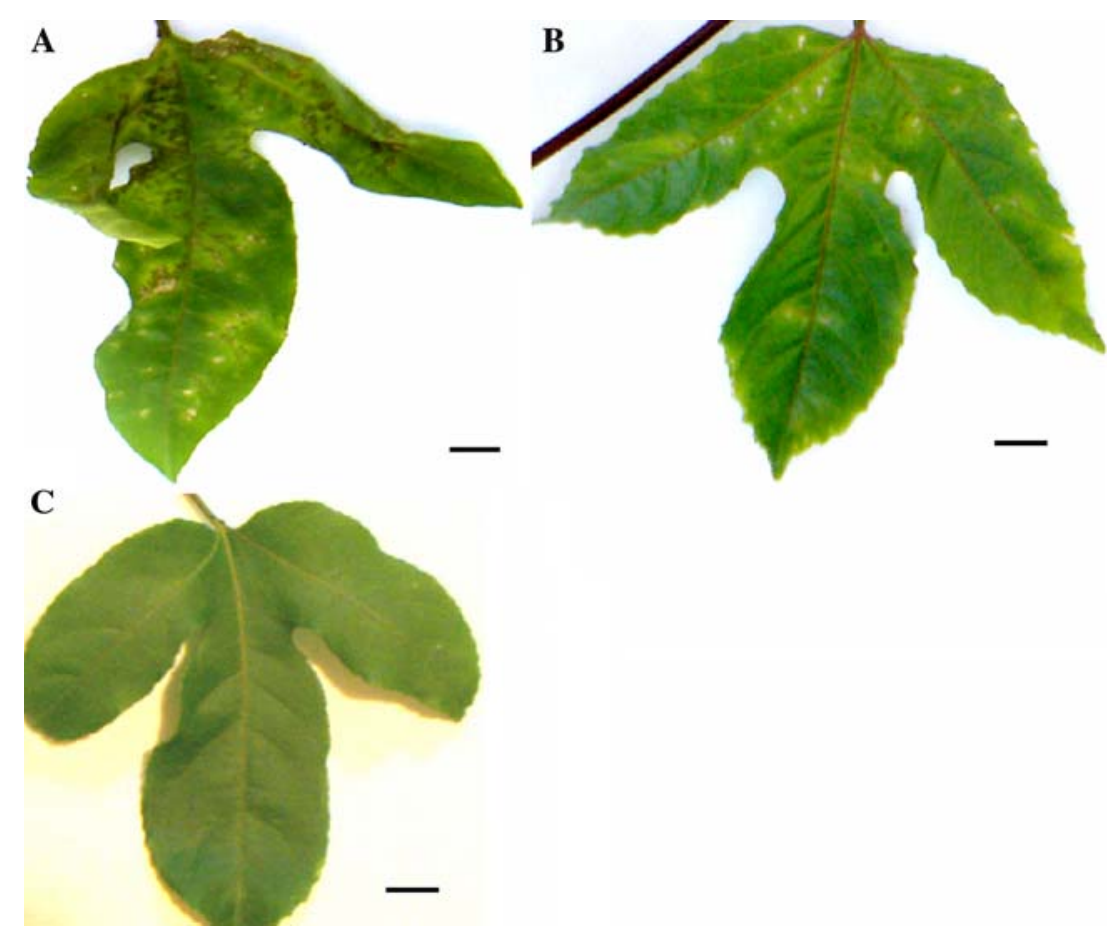

The infection by CABMV is characterized by the development of deformed small hard fruits and also mosaic symptoms in leaves; infected plants show low yield of fruits and die sooner (Nascimento et al. 2006). None of the transformed plants was resistant to CABMV, all of them showing the presence of chlorosis, mosaicism and leaf malformation (Fig. 3). However, initial symptoms in some plants $(\mathrm{A}, \mathrm{C}, \mathrm{D}, \mathrm{F}, \mathrm{G})$ were somewhat different from non-transformed plants (not shown) and showed chlorotic leaves as first symptom and then their growth was delayed until the establishment of disease at 45 days post inoculation. Tobacco plants expressing the anti-apoptotic genes $b c l-2, b c l-x L$ and ced-9 showed increased resistance to the tomato spotted wilt virus (TSWV), with fewer local lesions and preventing of the systemic spread of the virus (Dickman et al. 2001). Similar results were obtained with tomatoes expressing the $b c l-x L$ and ced-9 genes, when inoculated with cucumber mosaic virus D satRNA (CMV/D), demonstrating that in transgenic plants the expression of anti-apoptotic genes suppressed tomato PCD and altered the necrotic phenotype that occurs in CMV/D-infected non-transgenic tomato into more attenuated symptoms (Xu et al. 2004).

The herbicide glufosinate inhibits the glutamine synthetase enzyme, causing accumulation of ammonia, which in turn induces free radicals production that are toxic to plants (Chen and Dickman 2004). We observed glufosinate tolerance in eight plants (A, C, D, F, G, I, J and K), whereas three were not tolerant $(\mathrm{B}, \mathrm{E}$ and $\mathrm{H})$. Some transgenic plants (C, F and I) showed more tolerance than others. The P35 protein from AcMNPV is capable of inhibiting programmed cell death induced by different stimuli, including oxidative stress (Sah et al. 1999). Therefore, this could explain the increased tolerance of the transgenic passion fruits plants to the herbicide used in this work. Chen and Dickman (2004) also obtained increased herbicide tolerance in tobacco expressing anti-apoptotic genes $(b c l-2, b c l-x L$ or ced-9).

Xanthomonas axonopodis can cause severe disease in passion fruit and a great reduction in longevity, from the normal 3 to 4 years to something between 12 and 18 months (Ponte, 1996). The early death occurs at the end of the rainy season, and the pathogen induces small 
lesions in the leaves of around $1-2 \mathrm{~mm}$ in diameter, usually close to the venation. In severe infections, it can cause complete loss of leaves and death of the affected part or the whole plant itself. $X$. axonopodis induced fewer lesions in leaves from $p 35+$ plants when compared to nontransgenic plants. Lincoln et al. (2002), also showed that trangenic $p 35+$ tomato plants were protected against cell death induced by a fungal toxin (AAL-toxin from Aternaria alternata f. $\mathrm{sp}$ lycopersici) and other necrotrophic pathogens (Pseudomonas syringae pv tomato and Colletotrichum coccodes), leading to protection against the diseases caused by these pathogens.

We did not detect $p 35$ transcripts in only two p35+ plants ( $\mathrm{B}$ and $\mathrm{H})$. These two plants and another one (E) also were not tolerant to herbicide and $X$. axonopodis. These differences in tolerance may be attributable to different expression levels of P35 in the transgenic plants, which could reflect differences in the insertion of the p35 gene into the plant genome and in copy number.

This work shows for the first time that the introduction of a baculovirus anti-apoptotic gene into the genome of passion fruit results in an increased tolerance to a herbicide and to Xanthomonas axonopodis.

Acknowledgements We would like to thank Conselho Nacional de Desenvolvimento Científico e Tecnológico (CNPq) for a $\mathrm{PhD}$ grant to Daniele S. Freitas. We also acknowledge Dr. Nilton Junqueira from Embrapa Cerrados for the CABMV virus samples and Dr. Marisa Ferreira from the Phytopathology Department in University of Brasília for the bacterium Xanthomonas axonopodis pv passiflorae. We are also much indebted to Hugo Costa Paes for text draft revision.

\section{References}

Aragão FJL, Barros LMG, Brasileiro ACM, Ribeiro SG, Smith FD, Sanford JC, Faria JC, Rech EL (1996) Inheritance of foreign genes in transgenic bean (Passeolus vulgaris L.) co-transformed via particle bombardment. Theor Appl Genet 93:142-150

Callis J, Carpenter T, Sun C, Vierstra RD (1995) Structure and evolution of genes encoding poly-ubiquitin and ubiquitin-like proteins in Arabidopsis thaliana ecotype Columbia. Genetics 139:921-939

Chen S, Dickman MB (2004) Bcl- family members localize to tobacco chloroplasts and inhibit programmed cell death induced by chloroplast-targeted herbicides. J Exp Bot 8:1-7

Chichkova NV, Kim SH, Titova LS, Kalkum M, Morozov VS, Rubtsov YP, Kalinina NO, Taliansky ME, Vartapetian AB (2004) A Plant caspase-like portease activated during the hypersensitive response. The Plant Cell 16:157-171

Clem RJ (2001) Baculoviruses and apoptosis: the good, the bad, and the ugly. Cell Death Differ 8:137-43

Del Pozo O, Lam E (2002) Expression of the Baculovirus p35 protein in tobacco affects cell death progression and compromisses $\mathrm{N}$ gene-mediated disease resistance response to Tobacco mosaic virus. Mol PlantMicrobe Interac 16:485494

Dickman MB, Park VK, Oltersdorf T, Li W, Clemente T, French R (2001) Abrogation of disease development in plants expressing animal anti-apoptotic genes. Proc Natl Acad Sci USA 98:6957-6962

Ghosh S, Parvez KM, Banerjee K, Sarin SK, Hasnain SE (2002) Baculovirus as Mammalian Cell Expression Vector for Gene Therapy: An Emerging Strategy. Mol Ther 6:6-11

Hershberger PA, La Count DJ, Friesen PD (1994) The apoptotic supresor P35 is required early during baculovirus replication and is targed to the cytosol of the infected cells. J Virol 68:3467-3477

Khurana PSM, Pandey SK, Sarkar D, Chanemougasoundharam A (2005) Apoptosis in plant disease response: a close encounter of pathogen kind. Curr Sci 88:740-752

Li W, Dickman MB (2004) Abiotic stress induces apoptotic-like features in tobacco that is inhibited by expression of human Bcl-2. Biotechnol Lett 26:87-95

Lincoln JE, Richael C, Overduin B, Smith K, Bostock R, Gilchrist DG (2002) Expression of the anti-apoptotic baculovirus p35 gene in tomato blocks programmed cell death and provides broad-spectrum resistance to disease. Proc Natl Acad Sci USA 99: 15217-15221

Nascimento AVS, Santana EM, Braz ASK, Alfenas PF, Pio-Ribeiro G, Andrade GP, Carvalho MG, Zerbini FM (2006) Cowpea aphid-borne mosaic virus (CAB$\mathrm{MV}$ ) is widespread in passionfruit in Brazil and causes passionfruit woodiness disease. Arch Virol Published online April 7, 2006

Ponte JJ (1996)Clinica de doenças de plantas. Editora UFC, Fortaleza

Sah NK, Taneja TK, Pathak N, Begum R, Athar M, Hasnain SE (1999) The baculovirus anti-apoptotic p35 gene also functions via an oxidant-dependent pathway. Proc Natl Acad Sci USA 96:4838-4843

Sambrook L, Fritsch EF, Maniats T (1989) Molecular cloning: a laboratory manual. Cold Spring Hambor Laboratory, New York

Souza Jr MT, Gonsalves D (1999) Genetic engineering resistance to plant virus diseases, an effort to control Papaya ringspot virus in Brasil. Fitopatol Bras 24:485509

$\mathrm{Xu}$ P, Rogers SJ, Roossinck MJ (2004) Expression of antiapoptotic genes bcl- xL and ced- 9 in tomato enhances tolerance to viral-induced necrosis and abiotic stress. Proc Natl Acad Sci USA 101:1580515810 